\title{
YALE
}

\section{SOCIAL INSURANCE AND CONSTITUTIONAL LIMITATIONS}

Students of the development of constitutional limitations upon legislative power in the United States will find an interesting parallel in the history of the Roman confessional. Confronted with the alternative of adhering rigorously to the primitive standards of Christian conduct and of "contrition" for misconduct, or of relaxing these standards in the interest of hroadening its supervisior of the lives of its communicants, the Church has generally chosen the latter course. Similarly, it is the "laxists" rather than the "rigorists" who have determined the final character of our constitutional law.

Forty years ago constitutional law still rested in great part upon the foundations originally supplied it by eighteenth century political philosophy, upon the reciprocally implied yet reciprocally contradicted notions of the "sovereignty" of the state and the "natural rights" of the citizen. It thus resulted that, within a very broad field, the authority of the state legislature was treated as legally illimitable, at least in the absence of specific provision to the contrary, while in a much narrower field, comprising especially what were called "vested rights," private rights were treated as indefeasible. To-day constitutional law, both on its negative and on its positive side, is much more

flexible. On the one hand, judicial interpretation of the phrases "liberty," "property," and "due process of law," especially as these are used in the Fourteenth Amendment, leaves judicial control of state legislation with none but the vaguest limits. On the other hand, judicial definition of "the police power" as the power 
of the state to promote "the general welfare" by legislation "reasonably adapted" to that end, renders this widely extended supervision highly elastic.

But while this is true enough as a general statement of the matter, certain recent events make it clear that constitutional "rigorism" still maintains certain outposts from which it must be dislodged, if our system of constitutional limitations is to be adapted to the needs of modern complex society. The recent judicial utterance most to the point in this connection is the much debated decision of the New York Court of Appeals in the Ives case, ${ }^{1}$ in which a Workmen's Compensation act was overturned. The court admitted that the statute involved dealt with appreciable evils, that it had been drawn up with great care and only after diligent investigation, and that it met the best opinion on the subject. Yet in the face of these admissions, the act was pronounced void on two grounds: first, because it imposed "liability without fault" upon certain classes of employers and so, in effect, confiscated property of $A$ and gave it to $B$; secondly, because it comprised "an unreasonable regulation of the status of employment," and so deprived both employers and employees of their "freedom of contract." The obstacles interposed by this type of doctrine to Workmen's Compensation acts have since been overcome in a measure by what is known as the "elective" statute-but only in a measure ${ }^{2}$-and the menace of it to Minimum Wage legislation and other Social Insurance projects is apparent. And the general issue raised is even farther reaching. It is whether legislation, which is otherwise well within the police power, is to be treated as invalid because of its incidental detriment to private rights. This, in a word, is the issue between "rigorism" and "laxism" to-day.

The maxim that property cannot be transferred by act of government from one private owner to another is a landmark of our constitutional law. Indeed, it antedates our constitutional law, for it is stated by Coke, while on Coke's authority a Massachusetts magistrate of the seventeenth century pronounced void, on this ground, a town vote which was meant to provide the local minister with a dwelling-house at public expense. ${ }^{3}$ Though not

${ }^{1}$ Ives v. So. Buffalo Ry. Co. (I9II) $20 \mathrm{I}$ N. Y. z7I.

${ }^{2}$ See Ashton v. Boston and Maine Ry. Co. (Igr5) 222 Mass. 65.

${ }^{3}$ Giddings v. Brown, Select Essays in Anglo-American Legal History, Vol. I, p. 376 . 
explicitly recognized even to this day in any state constitution, so fundamental a principle of public morality soon found embodiment in judicially enforced limitations on legislative power. In early days the most obnoxious species of legislation from the point of view of vested rights was to be found in so-called "prerogative" acts, whereby legislatures frequently undertook to adjudicate private controversies. In combating this evil, the courts found the principle of the separation of powers and the maxim against confiscation for private benefit their most potent weapons. Thereafter the maxim was adduced in support of the principle that the power of eminent domain may be exercised for public purposes only; that is, for purposes deemed by the courts to be public. Later still, and on the same basis, a similar dogma was erected against the taxing power. ${ }^{4}$

Like most constitutional doctrines protective of private rights, this maxim has to-day been assimilated into the judicial theory of "due process of law." The form in which it confronts projects of Social Insurance is illustrated by a passage from Mr. Justice Holmes' opinion in the Oklahoma Bank Guaranty case which runs as follows:

"It is well established by a series of cases that an ulterior public advantage may justify a comparatively insignificant taking of private property for what, in its immediate purpose, is a private use."

This utterance, taken in its context, is not without its reassuring features. If the state may assess all banks to provide a fund from which to recoup depositors in banks which fail, why may it not assess employers to provide funds from which to recoup employees for losses growing out of their employment? No doubt if the court were bent on avoiding this conclusion, it could seek refuge behind the phrase "comparatively insignificant"; yet hardly securely. For if this phrase implies a limitation on the taxing power, it would seem that Mr. Justice Holmes' characteristic caution in expression had this time betrayed him into inaccuracy, since it does not appear that the insignificance of the taking has ever been a criterion with the courts in passing upon legislation challenged as confiscatory, when such legislation was referable to the taxing power; the sole question with the

-Loan Association v. Topeka (1874) 20 Wall. (U. S.) 655.

${ }^{8}$ Noble Bank v. Haskell (IgIr) 219 U. S. 104, I10. 
judges in such cases has always been whether an ulterior public interest was served. And with reference to this question, it seems to me that the entire implication of Mr. Justice Holmes' opinion is that the concept of "public purpose," as a limitation on the taxing power, is to be defined in light of the concept of "general welfare," as a dimension of the police power; that all the powers of the state march abreast and are of mutual serviceability.

Yet, it is just at this point that constitutional "rigorism" will enter a caveat. This will consist in drawing a sharp line between the powers of taxation and eminent domain, on the one hand, and the police power, on the other; and it will be argued that, whereas the former comprise, by very definition, the power to take property, the latter is a power of regulation merely, which does not and cannot extend to the taking of property, or to what is its equivalent, the compelling of its transfer from one person to another. Accordingly, it will be insisted that while the police power is a power to promote the public welfare, its ends must be achieved by the methods inherent to it. Otherwise, the settled boundaries between the great fields of governmental power will speedily become obliterated, and all powers will assume the guise of the one least susceptible of legal control, with the inevitable result that private rights, in any valuable sense, will soon be at an end.

This argument directs its appeal to that way of thinking which sets public policy and the security of private rights in sharpest antithesis, whereas the history of law proves that the recognition and protection of private rights by the state has always been a phase, though but one phase, of public policy. Furthermore, when we turn to the more readily accessible verdict of the history of constitutional limitations, we find that the line so insisted upon, as demarking regulation from taking, has been by no means a stationary one, and we accordingly feel warranted in questioning whether its present placement is necessarily so definite, after all. Thus, shortly before the Civil War, the New York Court of Appeals, in the famous Wynehamer case, ${ }^{6}$ set aside an anti-liquor law on the ground that, as to existing stocks of liquor, it constituted an act not of regulation but of destruction, and so of taking without just compensation. Thirty years later, in Mugler v. Kansas, ${ }^{7}$ the United States Supreme Court

- Wynehamer v. People (1856) I3 N. Y. 378.

? (I887) I23 U. S. 623 . 
sustained precisely the same kind of law as within the police power, to which, it said, all property is at all times held subject.

In other words, the state may, in the exercise of its police power, absolutely outlaw what was good property when it was acquired. But even as to property remaining under the protection of the law it may, by the same power, limit the owner's use and control thereof for the public benefit, ${ }^{8}$ and frequently for what, in its immediate aspect, is a private benefit. Thus the right of alienation may be restricted in the interest of creditors, dependents, and heirs-at-law ${ }^{9}$; while in directing the use of property held in common or in trust, and even of property held in severalty which without regulation could not be beneficially used, the state has large powers. ${ }^{10}$ Finally, the state may cast special obligations upon property which may be met only by expenditures for prescribed purposes. So the expenses of mine inspection may be charged against the owners of mines $^{11}$; of sanitary improvements, against the owners of tenements ${ }^{12}$; of constructing and maintaining grade crossings and suitable trackage connections, against railroad companies ${ }^{13}$; of laying and cleaning street sidewalks, against the owners of abutting premises. ${ }^{14}$ In none of these cases is there a taking in the sense of the term which is to-day established.

The problem may be approached from yet another angle. Consider for instance the decision of the United States Supreme Court in Hazeker v. New York. The appellant in this case had been convicted of the crime of abortion in New York, in 1878, and sentenced to ten years imprisonment. An act of the legislature, passed in 1893 and amended in I895, made it a misdemeanor for any person to practice medicine in the state after conviction of a felony. Hawker violated this statute, and appealed from his conviction under it on the ground that it violated the prohibition against ex post facto laws.

${ }^{8}$ Hudson County Water Co. v. McCarter (I908) 209 U. S. 349.

- Lemicux v. Young (I909) 2II U. S. 489.

${ }^{10}$ Head v. Amoskeag Mfg. Co. (1885) xr3 U. S. 9; Wurts v. Hoagland (I885) II4 U. S. 606.

"Charlotte, etc., R. R. Co. v. Gibbes (I892) I42 U. S. 386.

${ }^{12}$ Health Department v. Trinity Church (I895) I45 N. Y. 32.

${ }^{13}$ See C. B. \& Q.R. R. Co. v. Nebraska (I898) I70 U. S. 57 ; Wis., etc., $R$. R. Co. v. Jacobson (1900) 179 U. S. 287; C. B. \& Q. R. R. Co. v. Illinois ex rel. Drainage Commissioners (1905) 200 U. S. 56 r.

${ }^{14}$ Norwood v. Baker (I898) 172 U. S. 269. 
"On the one hand," said Mr. Justice Brewer, speaking for the Court, "it is said that defendant was tried, convicted, and sentenced for a criminal offense. He suffered the punishment pronounced. The legislature has no power to thereafter add to that punishment. . . . On the other hand, it is insisted that within the acknowledged reach of the police power, a state may prescribe the qualifications of one engaged in any business so directly affecting the lives and health of the people as the practice of medicine. . . We are of opinion that this argument is the more applicable and must control [the case]. . . . That the form in which this legislation is cast suggests the idea of the imposition of an additional punishment for past offenses is not conclusive. We must look at the substance, and not the form; and the statute should be regarded as though it in terms declared that one who had violated the criminal laws of the state should be deemed of such bad character as to be unfit to practice medicine, and that the record of a trial and conviction should be conclusive evidence of such violation."15

Could a better illustration be demanded of the triumph of "laxism" in our constitutional law, as I have earlier defined this tendency? Looked at from the point of view of its operation upon defendant's rights - which, as Mr. Justice Harlan's dissenting opinion shows was the better established point of view-the statute before the court was unquestionably an ex post facto law; but looked at from the point of view of its tendency to promote the ends of good government, it was within the police power; and despite the weight of precedent, the latter point of view prevailed. Why, then, should not the maxim against confiscation meet with the like fate, if confronted with a well-considered Minimum Wage or other Social Insurance scheme? Granted that in its immediate operation on private property, such a scheme would, by certain standards, be confiscatory; yet can it be denied that such a scheme would be calculated to further a widespread public interest? At least, it would seem that the constitutional issue must turn on this question, rather than on the question of alleged confiscation; and the more so since, as I have already indicated, the maxim against confiscation is to-day grounded on the "due process" clause, which, however, we have been repeatedly assured, does not override the power of the state to provide for the public health, safety, morals, and welfare. ${ }^{18}$

${ }^{15}$ Hawker v. New York (1898) I70 U. S. I89, I9r.

${ }^{16}$ See, especially, Atlantic Coast Line Co. v. Goldsboro (Igr4) 232 U. S. 548 , and cases there cited. 
But the applicability of the maxim forbidding confiscation to Social Insurance projects may be challenged from yet another point of view. This maxim prohibits the taking of private property save on certain conditions, which implies that the property whose taking is thus forbidden has become definitely vested, in accordance with the law, in some private owner. Thus the question arises, in accordance with what law is property so vested? No one, I take it, would deny that all businesses are subject, to a greater or less extent, to public regulation for the public good, notwithstanding the fact that profits may be thus more or less curtailed. Yet what is this but to admit that the owner of a business has no indefeasible right to the profits thereof until the obligations legally chargeable against these have been met? Undoubtedly a system of Social Insurance would comprise a lien upon business profits but, from what has already appeared, that fact would be far from classifying such a system as an invasion of vested rights.

We are thus brought to consider the second objection to Social Insurance legislation: the objection that the police power does not extend to the regulation of the status of employment, at least in the case of persons sui juris. In the Ives case the decision of the United States Supreme Court in Lochner v. The People of New York ${ }^{17}$ was cited for this proposition, but, I think quite unwarrantably. The Lochner decision is undoubtedly open to criticism for the assumption which it makes that the welfare of the public is not affected by the hours of work of able-bodied laborers engaged in ordinary employments, but it clearly admits that the "freedom of contract," whether of employer or employee, is subject to the state in the reasonable exercise of its police power. And the more recent decision in Coppage $v$. Kansas, ${ }^{18}$ which is also frequently cited in this connection, repeats the admission, albeit the Court fails to take the "judicial cognizance" which it has in other cases, of the actual disadvantage of employees in entering into contracts with large employers. ${ }^{10}$ Moreover, if the concept of "freedom of contract" amounts to anything, it ought to secure an owner at least as great liberty of action in making contracts of sale as in making

\footnotetext{
${ }^{27}$ (I905) I98 U. S. 45.

${ }^{13}$ (IgI5) 236 U. S. I.

${ }^{2}$ Holden v. Hardy (I8g8) I69 U. S. 366; Knoxville Iron \& Coal Co. v. Harbison (Igor) 183 U. S. I3; McLean v. Arkansas (Ig09) 2 II U. S. 539 .
} 
contracts of employment. Yet it is established doctrine that if a business is so widespread as to be of really public concern, the state may regulate its charges, and that independently of any right in the public to claim the service of the business. ${ }^{20}$

The question of the constitutional validity of Social Insurance depends, therefore, it seems to me, upon the existence of "a real, a substantial" relation ${ }^{21}$ between a well-considered measure embodying the idea and the public welfare, or rather, perhaps, upon the existence of a widespread public conviction that there is such a relation. ${ }^{22}$ Granted this much, and all other questions become impertinent. Nor does this signify, by any means, the negation of constitutional limitations: on the contrary, it signifies the affirmation of that species of constitutional limitations which already control in the great majority of cases touching the relation of legislative power and private rights.

Thus for one thing, it must be the public welfare which is to be promoted by legislation demanding vindication by this sort of test, not simply the welfare of an individual or a class. The recent Adamson Act may be considered as a case in point. 'Its immediate benefits are to go to a comparatively restricted group of workmen while the claims of other groups better entitled by equity to legislative intervention in their behalf are ignored. It is true that the enactment of the measure may be reasonably thought to have averted a crisis, but in such a way as to invite its recurrence at any time, while the precise provisions of the act bear only the remotest relation to the public welfare. Also, far from springing from a widespread public conviction of its necessity, it is notorious that this statute came as a complete and most unpleasant surprise to almost everybody, while the ambiguity of its provisions attests in the most striking fashion their entire lack of constitutional bona fides. Nevertheless, I think that the purport of these provisions, expressed unambiguously, and embodied in a general scheme betokening the intention of Congress to put the relations of the great carriers and their employees on a stable and equitable basis, would stand

${ }^{20}$ Munn v. Illinois (I876) 94 U่. S. II3; German Alliance Insurance Co. v. Lewis (I914) 233 U. S. 389 .

${ }^{21}$ Powell v. Pennsylvania (1888) I27 U. S. 678.

${ }^{2}$ C. B. \& Q.R.R. Co. v. McGuire (IgII) 219 U. S. 549; Otis v. Parker (I903) I87 U. S. 606; Noble Bank v. Haskell, supra; Price v. Illinois (I9r5) 238 U. S. 446; Laurel Hill Cemetery v. San Francisco (1910) 216 U. S. 358 . 
on a far different footing legally-that they would, in fact, be constitutional. ${ }^{23}$

In the second place, however, the word "welfare" itself has certain implications that are not to be disregarded in determining the scope of legislative authority. From time immemorial the concept of public welfare and that of justice between man and man have existed side by side, taking color each from the other. So far, therefore, as such decisions as those in the Ives and Coppage cases imply that the "public welfare" is not to be defined regardless of what is rightly due from one man to another in a given situation, they are entitled to all respect. But this is far from conceding that the legal standards of justice that have come down to us from the past are to-day always adequate. Take for instance the rule against "liability without fault." As expressed in the common-law doctrine of the "assumption of the risks of the trade" and as applied to the facts of modern machine industry, the rule is the merest solecism-a contradiction in terms. Again, consider Mr. Justice Pitney's suggestion in the Coppage case, that the Constitution does not permit a legislative distribution of the natural and inevitable advantages of wealth. Of course not; but neither does it forbid the elimination of many of the inequities that disparity of wealth and economic power produce. For the purpose of the Constitution in protecting wealth was to "establish justice" and "promote the general welfare," and such presumably is its purpose still.

The phrase "social justice" is one that has fallen into some disrepute of late on account of the abuse of it by enthusiasts, and so circumspect folk generally give it wide berth. It has none, the

${ }^{2}$ The recent decision of the Supreme Court, Wilson v. New and Ferris, Receivers (March I9, I9I7) Oct. Term, 1916. No. II5, sustaining the Adamson Act seems to be based on the proposition that the act was an allowable measure in meeting an extraordinary emergency which threatened the total interruption of interstate commerce. The Court takes very broad cognizance of the circumstances constituting the emergency. Feeling as I do that the emergency was largely the result of the means employed by the Government in meeting it, I must express my sympathy with the views of the minority of the Court. The words of Mr. Justice Day seem especially appropriate:

"Inherently, such legislation requires that investigation and deliberation shall precede action. Nevertheless, Congress has in this act itself declared the lack of sufficient information and knowledge to warrant the action taken, and has directed an experiment to determine what it should do.

"Such legislation, it seems to me, amounts to the taking of the property of one and giving it to another in violation of the spirit of fair play and the due process clause." 
less real meaning, and especially does it call attention to the fact that the community as a whole ought to shoulder the burdens of modern community life, rather than those classes which are often made to do so precisely because they are least capable of doing it. In the simple economy of a frontier society, it was at once equitable and expedient to leave to the determination of accident, or private contract, many relationships which the more closely interwrought industrialized society of to-day must, both in justice to its weaker members and in support of the defensive powers of society, undertake to control directly. Hence the movement for a rational system of Social Insurance. The old time direct personal contact between master and servant has long since largely vanished from the world of production, but it is coming to be appreciated that the newer impersonal relationship of capital and labor is not devoid of moral responsibilities on both sides which the state is frequently warranted in attempting to elevate to legal responsibilities. Moreover, while the economic burden of Social Insurance must fall primarily upon investment capital, ultimately it will come to rest, as part and parcel of the whole cost of production, upon society at large. Nor is this to say that the courts must take cognizance of the speculations of political economists; for they can and do take cognizance of the practices of industry and commerce ${ }^{24}$; and at any rate it must be presumed that they may do whatever is necessary to a beneficial exercise of their powers.

It is, therefore, incredible that an intelligent tribunal would to-day endeavor to classify a well-considered Minimum Wage law, Workmen's Compensation law, or Social Insurance law with bills of pains and penalties, legislative forfeitures, or acts of confiscation, or as an attempt to limit "freedom of contract" unreasonably and arbitrarily. "Jurisprudence," the Court itself has informed us, "is a progressive science."25 No doubt the admission may be unfairly stressed, since the normal function of the law is conservative, and not even the reformer would have it otherwise, once he has attained his objective. Still the fact remains that constitutional principles, which interpreted very adequately the needs of a prosperity resting upon individual thrift and exertion, to-day leave a great part of the industrial organism sprawling outside the legal shell. Such a situation,

${ }^{24}$ Robbins v. Shelby County Taxing District (I887) I20 U. S. 489.

${ }^{25}$ Holden v. Hardy, supra. 
clearly, cannot endure nor be endured indefinitely. This would be the fact even though we could be confident henceforth of the immunity we have so long enjoyed from troublesome international relationships; the appreciation that we cannot enjoy such immunity only makes the problem the more imperious. And this is to say that the great effort toward national reorganization which is to-day just getting under way and the goal of which we have labelled "preparedness" has its constitutional phase, the solution of which will, necessarily, fall in considerable part to the courts. In endeavoring their task, the judges cannot do better than to hark back to the view of our Constitution with which Chief Justice Marshall essayed so successfully a similar work-the view of it as an instrument "intended to endure for ages and consequently to be adapted to the various crises of human affairs."2B

Since the foregoing was written the Supreme Court has rendered two decisions of much significance in connection with the matters herein discussed. In the New York Central Railroad Co. v. White ${ }^{27}$ it sustained the recent New York Workmen's Compensation Act, and in the Mountain Timber Co. v. Washington ${ }^{28}$ it upheld the Washington statute. Both these acts are of the "compulsory" type and govern hazardous employments, but there is this important difference between them. Whereas the New York act leaves the employer free to insure himself against the risks which it creates and accordingly puts it in his power to lessen these and the consequent expense by careful management, employers under the Washington statute must make an annual contribution to a state fund which is proportioned to the number of their employees entirely regardless of the extent to which injury has befallen such employees.

In the New York case Chief Justice White, speaking for a unanimous court, had little difficulty in disposing of the "liability without fault" argument. The idea, said he, "is not a novelty in the law," citing the common-law liability of innkeepers, the rule as to dangerous things, and the principle of respondeat superior. "In excluding the question of fault as a cause of injury," he continued, "the act in effect disregards the proximate cause and looks to one more remote- the primary cause, as it

${ }^{20} \mathrm{McCulloch}$ v. Maryland (I819) 4 Wheat. (U. S.) $316,415$.

${ }^{27}$ (March 6, I9I7) U. S. Sup. Ct., Oct. Term, I9I6. No. 320.

${ }^{28}$ (March 6, I9I7) U. S. Sup. Ct., Oct. Term, 1916. No. I3. 
may be deemed-and that is the employment itself." Also, he shrewdly pointed out that, "just as the employee's assumption of ordinary risks at the common law presumably was taken into account in fixing the rate of wages, so the fixed responsibility of the employer [under the new system] presumably will be reflected in the wage scale."

The Washington case was decided by a closely divided court, Justice Pitney speaking for the majority. "The crucial inquiry under the Fourteenth Amendment," said he, "is whether it [the act] appears to be noi a fair and reasonable exertion of governmental power, but so extravagant or arbitrary as to constitute an abuse of power." The following passage from the Court's answer to this question is of such importance from the point of view of Social Insurance projects that it deserves extensive quotation:

"Special burdens are often necessary for general benefits-for supplying water, preventing fires, lighting districts, cleaning streets. - . Regulations for these purposes may press with more or less weight upon one than another, but they are designed, not to impose unequal or unnecessary restrictions on anyone, but to promote, with as little individual inconvenience as possible, the general good. . - Certainly, the operation of industrial establishments that in the ordinary course of things frequently and inevitably produce disabling or mortal injuries to the human beings employed is not a matter of wholly private concern. It hardly can be questioned that the state might expend public moneys to provide hospital treatment, artificial limbs, or like aid to persons injured in industry, and home or support for the widows or orphans of those killed. Does direct compensation stand on less secure ground? A familiar exercise of state power is the grant of pensions to disabled soldiers and to the widows and dependents of those killed in war. Such legislation usually is justified as fulfilling a moral obligation or as tending to encourage a public duty of defense. But is the state powerless to compensate with pensions or otherwise those who are disabled, or the dependents of those whose lives are lost, in the industrial occupations that are so necessary to develop the resources and add to the wealth and prosperity of the state? A machine as well as a bullet may produce a wound . . . . ; the workman is the soldier of organized industry accepting a kind of pension in exchange for absolute insurance on his master's premises.' Stertz v. Industrial Insurance Commission, I58 Pac. Rep.; 256, 263. It is said that the compensation or 
pension under this law is not confined to those who are left without means of support. This is true. But is the state powerless to succor the wounded except they be reduced to the last extremity? Is it debarred from compensating an injured man until his own resources are first exhausted? This would be to discriminate against the thrifty in favor of the improvident. The power and discretion of the state are not thus circumscribed by the Fourteenth Amendment."

It seems to me that this utterance by the Justice who spoke for the Court in the Coppage case goes very far indeed to dispense with the notion of an indefeasible right of either property or contract as against the reasonable exercise by the state of its police powers. In other words, constitutional "rigorism" is at an end.

Edward S. Corwin.

Princeton Untversity. 